\title{
Biodiversity and habitat use of wintering and breeding waterbirds in Burullus Lake (Ramsar site), Egypt
}

\author{
Basma M. Sheta \\ Zoology Department, Faculty of Science, Damietta University, 34517 New Damietta, Egypt
}

\begin{abstract}
The present study seeks to assess the bird biodiversity at the Important Bird Area (IBA) and Ramsar site, Lake Burullus, northern Egypt. Waterbirds biodiversity was assessed at 14 selected sites in the lake during winter and spring seasons. The assessment included richness, composition, evenness, abundance, and Simpson and Shannon-Wiener diversity indices. Bird species diversity varied spatially and temporally among different sites during the study period. Estimated species richness was 49 species. Winter birds were mainly migratory waterbirds like waterfowl, distributed in the islets for foraging, which was the main activity of $51 \%$ of total birds, followed by $36 \%$ roosting and $13 \%$ breeding at the lake. Evidence of breeding was recorded, such as collecting nest material, courtship behavior and food collecting for juveniles. The hierarchical cluster analysis separated the lake sites into four distinctive habitats: lake shores, open water, islets and reed beds. Seven bird species showed significant affinities with different habitat types: Laughing dove (Streptopelia senegalensis) favored the lake shores habitat $(P<0.04)$; Little bittern (Ixobrychus minutus) $(P<0.04)$, Pied kingfisher (Ceryle rudis) $(P<0.04)$, Common kingfisher (Alcedo atthis) $(P<0.02)$, Pied wagtail (Motacilla alba) $(P<0.04)$, and Graceful prinina (Prinia gracilis) $(P<0.01)$ were found in islands habitat. Little egret (Egretta garzetta) dominated the reed beds habitat group $(P<0.03)$. The results reflected the importance of Burullus Lake as a wintering and breeding habitat for birds and suggested that more implemented conservation and management strategies should be adopted.
\end{abstract}

Keywords: Waterbirds, habitat use, Burullus Lake, Ramsar, IBA, Bird monitoring.

\section{INTRODUCTION}

Wetlands have great economic value as rich ecosystems supporting biodiversity and playing a role in ecosystem services such as purification of water and sediment flow control (Robledano et al., 2010). Also, they are considered a cultural heritage and sometimes have moral value. Wetlands are the main home of waterbirds (Rajpar et al., 2013), offering them all essential requirements like food, nest materials and shelter for migratory birds during migration season (Xia et al., 2017; Francesiaz et al., 2017). Severe land use and anthropogenic activity has led to drastic losses of more than half of the world's wetlands (Ma et al., 2010), which, in turn, threatens all biodiversity, especially waterbirds. Ramsar Convention is one of several remarkable efforts made to safeguard and protect the world's wetlands (Ramsar Convention Secretariat, 2016). A total of 2000 wetlands all over the world have been designated as Ramsar sites, covering an area of about 215 million hectares (Tiega, 2011).

Egypt occupies a central position in the main migration routes of migrating birds from Europe to Africa. The northern lakes of Egypt, including Bardawil, Manzala, Burullus, Idku and Maryout are important strategic stops for wintering migratory birds, and homes for breeding birds (Meininger et al., 1986; Meininger and Atta, 1994; Shreadah et al., 2014). Thousands of migratory waterbirds stop at northern lakes each year, especially in the autumn and spring, to refuel before their final destination to the Sahara or back home across the Mediterranean (Green et al., 2002). Northern lakes are also considered the home of wintering for waterbirds during winter (Sayoud et al., 2017). Lake Burullus is located on the north coast of Egypt. It is an Important Bird Area (IBA) and has been designated an important wetland under the Ramsar Convention, to which Egypt is a signatory (Bird Life
International, 2018). Its location in northern Egypt on the Mediterranean coast, midway between the two mouths of the Nile River, makes it an important wintering site for migratory waterbirds, while its floral structure offers suitable habitats for roosting and nesting resident waterbirds. Although there are many human activities and settlements around and on the lake, it is still considered a semi-wild environment, including large reedbeds and small islands that make it very good habitat for wintering and breeding birds. One of the main environmental components in Burullus Lake are the dense reed beds that offer good shelter for migratory birds like song birds and waterbirds and roosting places for all breeding birds inhabiting the lake during the breeding season. Human settlement, increased human population and the projects around the lake have increased during the last decade, which is expected to greatly affect biodiversity (Masoud et al., 2011). Studying birds is a useful tool and indicator to measure such impacts on biodiversity.

Research conducted on Lake Burullus has focused primarily on heavy metals assessment and studies of water, sediments, plants, invertebrates, fishes, and fisheries (Farag and Elgamal, 2011; Shreadah et al., 2014; El-Kafrawy et al., 2015; El-Bana, 2015). The only published survey of breeding birds in the Nile Delta lakes, including Lake Burullus, was that by Meininger et al. (1986) and Meininger and Atta (1994). Since then, there have been only occasional bird observation records around the lake, coming only from scattered and occasional visits by foreign birding tourists, who had no access to the middle of the lake. During the period from January 1 st to February $9^{\text {th }}$, 2013, the International Waterbird Census (IWC) conducted waterbird counts in Northern African lakes, including Lake Burullus. They recommended more intensive sampling efforts to assess waterbird popu- 


\section{Waterbirds biodiversity in Burullus lake Ramsar}

lation sizes, especially on a temporal scale (Sayoud et al., 2017).

To cover this gap of bird community data for Burullus, the present waterbird survey was conducted in successive winter and spring seasons from January to May 2018. This study seeks to describe the current status of waterbird communities, spatially and temporally. It is hoped this will assist in implementing new conservation action plans for the lake.

\section{Study Area}

Burullus Lake is located at the northern part of the Nile delta on the eastern side of Rosetta branch of the Nile $\left(30^{\circ} 22^{\prime}-31^{\circ} 35^{\prime} \mathrm{N} ; 30^{\circ} 33^{\prime}-31^{\circ} 08^{\prime} \mathrm{E}\right)$ with an area of around $460 \mathrm{~km}^{2}$ (El-Kafrawy et al., 2015). It possesses a focal position along the Mediterranean shore of the Nile Delta. The length of the lake is around $53 \mathrm{~km}$, its width is around $13 \mathrm{~km}$, and its water profundities run from 0.5 to $2.5 \mathrm{~m}$ (Shaltout and Khalil, 2005). It interfaces with the sea through a limited strait inlet at its upper east side. There are 50 islands scattered throughout the lake. There are saltmarshes and mudflats in the north. The southern region is circumscribed by a thick reed-swamps consisting mostly of Phragmites and Typha, covering more than $25 \%$ of the lake area. Lake Burullus has rich submerged vegetation, commanded by Potamogeton, which is densest in the southern segment of the lake. It is the second biggest common lake in Egypt after Lake Manzala. Lake Burullus is one of a network of protected areas throughout Egypt, designated and managed by the Egyptian Environmental Affairs Agency. It is enlisted as a Ramsar site and BirdLife International has recognized it as an Important Bird Area (IBA) (BirdLife International, 2018). The lake gets a yearly water volume of around 4.1 milliard cubic meters through an arrangement of eight drains and a fresh water canal. In Burullus, the air temperature ranges from $11.2{ }^{\circ} \mathrm{C}$ in January to $23.6{ }^{\circ} \mathrm{C}$ in August with a mean yearly temperature of around $17.3^{\circ} \mathrm{C}$.

\section{Waterbird census}

Bird surveys were conducted monthly at 14 sites around the lake (Fig. 1) in two successive seasons: winter, which is the peak migration season, and spring, which is the peak breading season, to cover all resident and migratory birds. In each site, all birds observed or heard were recorded. Each site was a representative of an area of $250 \times 250 \mathrm{~m}$. Habitat structure in each site was assessed. Evidence of breeding behavior including singing, chirping, carrying nesting material, and feeding fledglings was recorded. Habitat use and daily activities were also recoded.

\section{Data Analysis}

All statistical analyses including richness, mean abundance, evenness, Shannon's diversity index and Simpson's index were calculated using PC-ORD program Version 6.12 (McCune and Mefford, 2011). The spatial data has been grouped according to the four habitat types as following: lake shores, open water, islets, and reed beds. The temporal data were classified into winter and spring seasons data. One-way analysis of variance (ANOVA) and Tukey's (HSD) test were used to evaluate the statistical differences between habitat groups and t-test was used among the 2 seasons. Two-way ANOVA was used to identify the difference in bird species richness among orders and different habitat types. Also, Hierarchical Cluster Analysis was done to group sites based on mean bird species abundance. The analysis of indicator species has been done according to the Duferne and Legendre (1997) method to identify which species related to or with inductive group (Bakker, 2008).

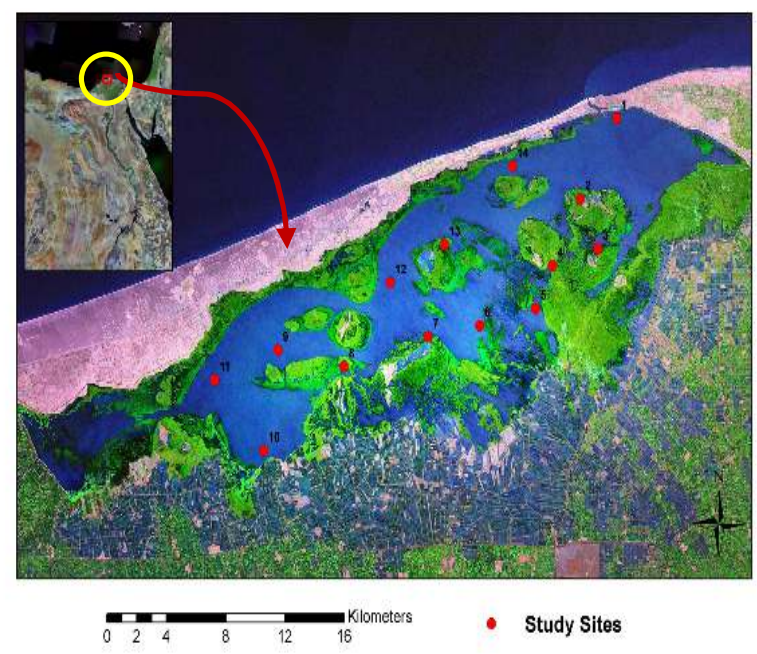

Figure(1): Satellite map of the study area showing Burllus Lake close to the Mediterranean Sea. Numbered (1-14) red circles are the study sites.

\section{RESULTS}

\section{Community composition}

A total of 34425 individuals belonging to 49 bird species, 23 families and 12 orders were recorded throughout the study period on two successive winter and spring seasons at the 14 points covering the lake (Appendix 1). Of these, waterbirds were the most abundant species, representing $55 \%$ of total bird community, while the remining $45 \%$ included all other species such as passerines and raptors.

The lake consists of four main habitat; lake shores, open water areas, islets and reed beds. Each habitat was inhabited by specific species. Species restricted to reed beds constituted $54 \%$ of total birds, while $32 \%$ were recorded in open water areas and $14 \%$ used both types of habitats. Waterbirds like Cormorants, ducks and gulls were more abundant in winter, whereas insectivorous and breeder birds associated with reed beds habitat were more frequently recorded in spring.

\section{Activity and habitat use by bird species}

Overall, $51 \%$ of birds foraged on the lake, while $36 \%$ came for breeding and $13 \%$ of birds roosted at the lake. The islet habitat showed high habitat preference by birds' daily activities like foraging (21.6 \pm 0.154$)$, roasting $(16.66 \pm 0.11)$ and seasonal activity like breeding (9.33 \pm 0.042$)$. A significant difference in for aging activity (Fig. 2A) was observed among the different habitat type $(P<0.0008)$. There were no 
significant differences between different habitats for roosting and breeding activities (Fig 2B, 2C).
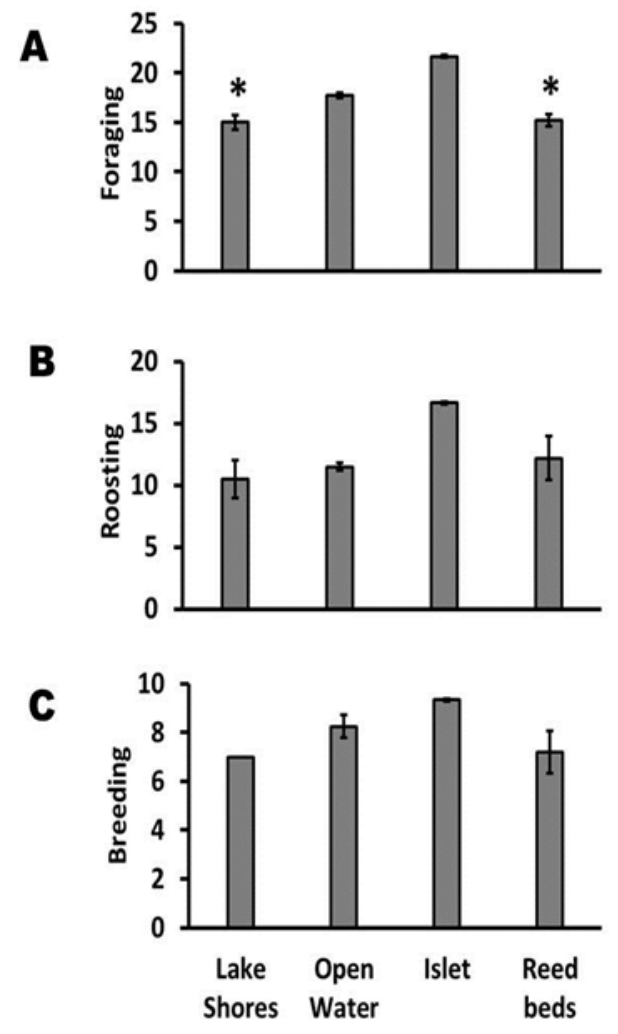

Figure(2): Activity of bird species inside the lake at the different habitat types: (A) Foraging activity, (B) Roosting activity, (C) Breeding activity. Values are in mean \pm SEM. Statistical analysis was performed by one way ANOVA between groups. $P=0.008$ in (A); no significant differences were recorded in groups (B) and (C). The * denotes significantly lower values compared to the other 2 values.

\section{Bird Species Richness among different lake habitats}

A total of 49 bird species were recorded in the lake during the study period. Figure 3 Shows that bird richness was spatially different across the different habitat groups $(P<0.0008)$. Islet habitat showed the highest record of bird species richness $(23 \pm 0.133)$ with highest species richness within the group recorded in site $2(\mathrm{~S}=26)$, which was characterized by dense reed beds. Lake shores, which were dominated by human activities like fishing and grazing, had the lowest richness (15 \pm 1 ) (Fig. 3A). Resident birds comprised $61 \%$ while the migratory birds were $39 \%$ of the entire recorded birds. There were no significant differences between resident bird species among different habitat types $(P<0.08)$ with maximum record at open water group (14.75 \pm 0.478$)$ (Fig. 3B). In contrast, migratory birds significantly differed in different habitat types $(P<0.004)$, with highest number recorded in islet group (8.66 \pm 0.07$)$ (Fig. 3C).

\section{Bird species abundance, evenness and diversity}

The reed beds habitat showed the highest bird species total abundance. Splitting the data showed that resident birds were found mainly in islet habitat while Migratory birds were mainly at reed beds (Table. 1).
There was no significant difference between different study sites in total species abundance, resident and migratory abundance.

Species evenness varied from the lowest within reed beds group to the highest record in lake shores habitat group, (Table.1). Statistically, there was no significant difference between different study sites in species evenness.

The spatial variation in Simpson diversity index (D) and Shannon-Wiener diversity index $(\mathrm{H})$ around the lake is represented in (Table.1). The highest values of species diversity were in islets habitat group recorded by both indices. Simpson diversity index showed a significant difference between different sites $(P<0.03)$; while no significant difference was observed for Shannon diversity index.

$\mathbf{A}$

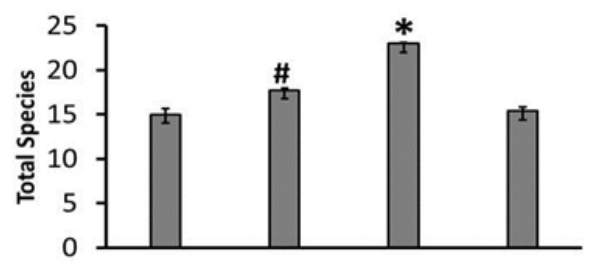

B
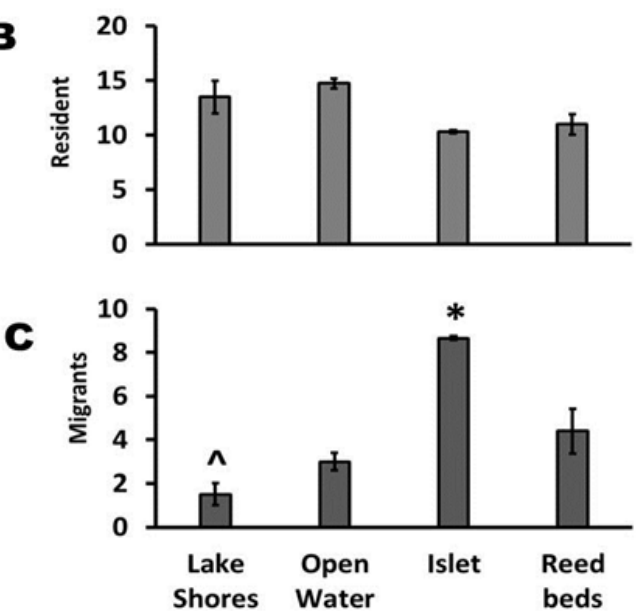

Figure(3): Comparison of bird species richness among the different habitat types, (A) Total species richness; (B) Resident species richn-ess; (C) Migratory species richness. Data are presented in mean \pm SEM. Statistical analysis was performed using one way ANOVA between groups. $P<0.0008$ in (A), $P=0.004$ in $(\mathrm{C})$ and no significant difference within (B). The * denotes significantly higher value than all other values, $\#=$ significantly higher than the other 2 values, and ${ }^{\wedge}=$ significantly lower than the open water group value.

\section{Temporal pattern of variation:}

Figure 4 reflects how the temporal trends for bird community differ seasonally and monthly. Winter season showed higher mean species richness $(27 \pm 1)$ than spring (24.3 \pm 3.7$)$ (Fig. 4A). However, the richness reached its maximum in March $(\mathrm{S}=29)$ and the minimal richness was recorded in April $(S=17)$, reflecting how monthly records are important to track avian species trend. (Fig. 4B). The data showed no significant difference in species richness between different seasons.

Resident bird species exhibited the highest abundance in spring $(3947 \pm 3208.87)$ (Fig. 4C). In 


\section{Waterbirds biodiversity in Burullus lake Ramsar}

contrast, migratory birds showed the highest abundance during winter season $(9646 \pm 3660)$ (Fig. 4D). There was a significant difference in migratory bird abundance $(P<0.01)$ between both seasons, while the difference in resident species abundance was statistically non-significant. The maximal species total abundance was recorded in winter season (11133 $\pm 3904)$ in February, while spring season had lower species total abundance (4053 \pm 3173.2$)$, with minimum record in April (Fig. 4E).

Evenness, Simpson and Shannon diversity indices appeared to be increased towards spring season. The maximal species evenness was $0.54 \pm 0.033$ (Fig. 4F).
There was a significant difference between the 2 seasons in species evenness $(P<0.007)$.

The spring recorded significantly higher value $(P<$ $0.01)$ of temporal variation in Simpson diversity $(0.737 \pm 0.038)$ than the winter value (Fig.4G). Similarly, the Shannon-Wiener diversity index showed again that spring recorded the highest value of temporal variation $(1.72 \pm 0.138)$ (Fig. $4 \mathrm{H})$. There was a significant difference in Shannon diversity index between the 2 investigated seasons $(P<0.01)$.
A
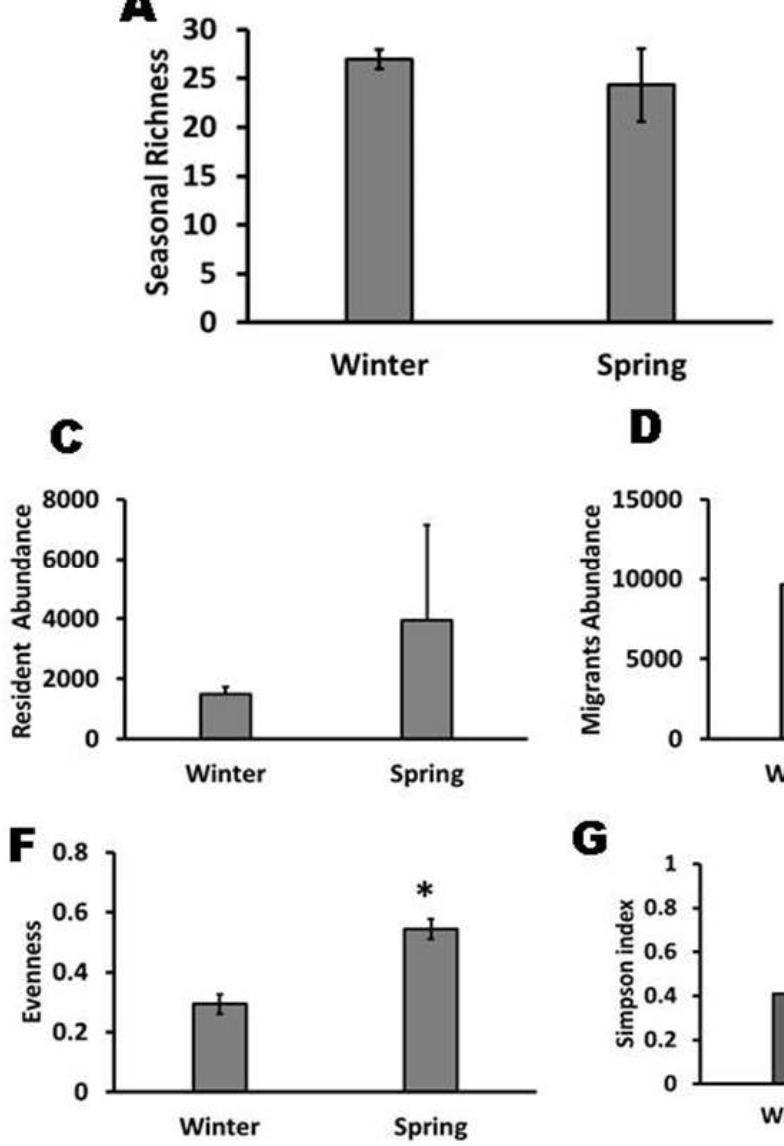

D

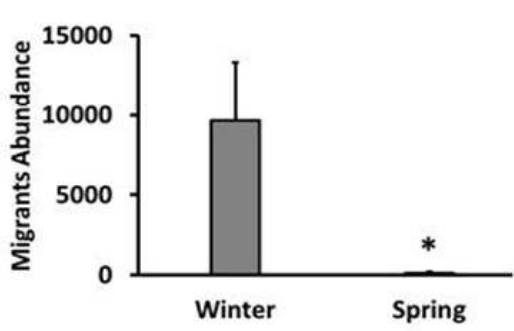

G

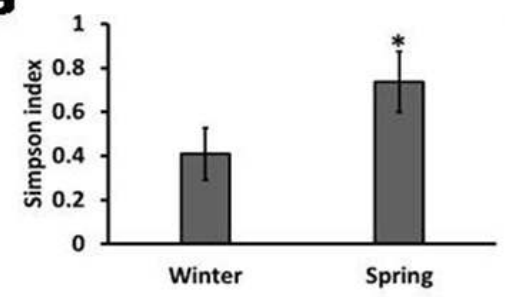

B
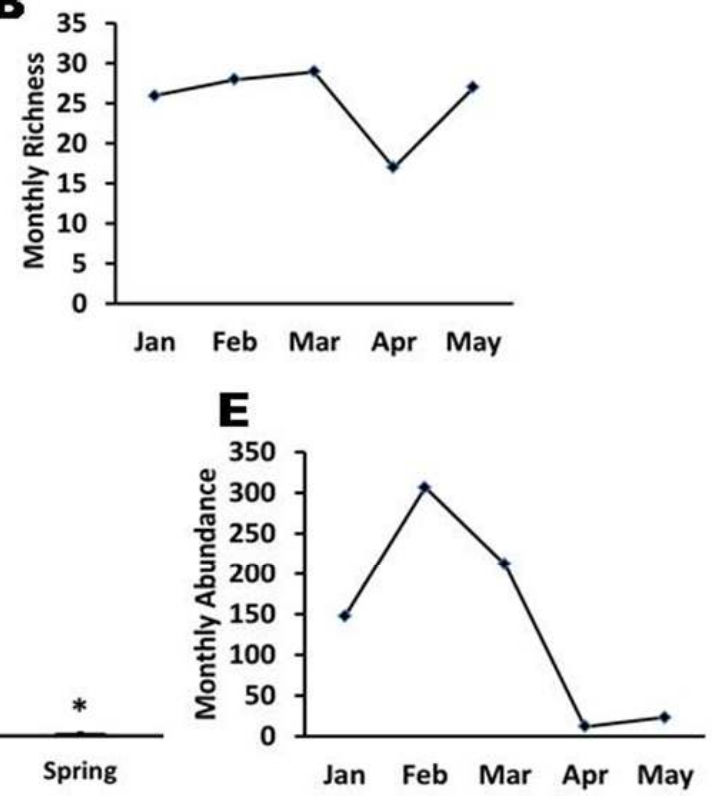

H

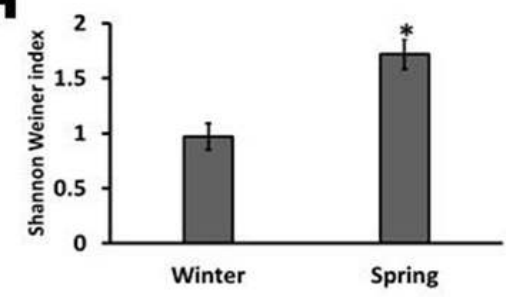

Figure(4): The temporal pattern variation of bird species in Lake Burullus. (A) Seasonal richness, (B) Monthly variation in Richness, (C) Abundance resident birds, (D) Abundance of migratory birds, (E) Monthly variation in total abundance, (F) Seasonal evenness, (G) Simpson diversity index, and $(\mathrm{H})$ Shannon Weiner diversity index. Data are presented as mean \pm SEM. Statistical analysis was performed by unpaired ttest; * denotes significance at $P<0.05$ between the studied groups.

\section{Species richness among different bird orders}

The observed bird species were found to belong to 12 orders. Figure 5 shows that the number of species varied between different orders of birds. There were a significant variation between different orders (F (11, $47)=22.59, P=0.000)$ and between different habitat groups $(\mathrm{F}(3,47)=5.95, P<0.002)$. The most highly represented orders were Charadriiformes and Passeriformes. Charadriiformes order included gulls, terns and plovers and showed higher habitat preference to open water then to reed beds habitats. Also, Passeriformes showed higher presence in open water areas followed by islets habitat. Ciconiiformes order including the heron family were recorded in all habitat

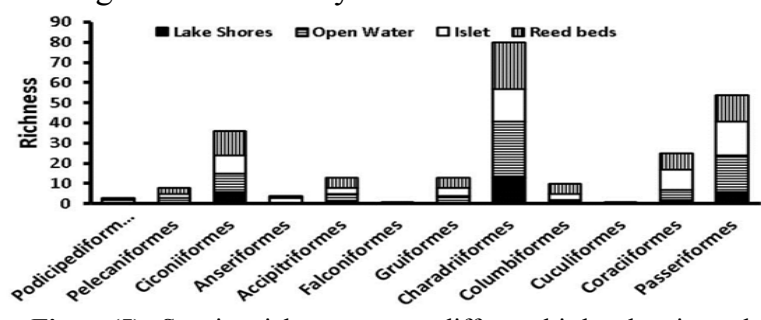

Figure(5): Species richness among different bird orders in each habitat of Lake Burullus. Significant differences were recorded by two ways ANOVA between orders and habitats. 
Sheta, B.M.

groups with higher representation in reed bed habitat.

Nevertheless, the data of orders Cuculiformes and
Falconiformes were restricted only to the reed beds' sites.

Table(1): Spatial pattern of diversity including Total Abundance of bird species (TA), Resident Abundance; (RA), Migrant Abundance (MA), evenness ( E), Simpson diversity index (D); and Shannon Weiner diversity index (H). Statistical analyses revealed no significant differences among groups for each items.

\begin{tabular}{lllll}
\hline \hline \multirow{2}{*}{ Measured parameter } & \multicolumn{4}{c}{ Habitat groups } \\
\cline { 2 - 5 } & Lake Shores & Open water & Islets & Reed beds \\
\hline TA & $2471 \pm 2191$ & $1972 \pm 1008$ & $1654.3 \pm 60.28$ & $3348.2 \pm 2960$ \\
RA & $2401 \pm 2192$ & $1796 \pm 879$ & $1332.6 \pm 56.6$ & $302.6 \pm 48.1$ \\
MA & $16 \pm 1.00$ & $176 \pm 130.4$ & $321.6 \pm 7.9$ & $3045.6 \pm 2993$ \\
E & $0.579 \pm 0.225$ & $0.558 \pm 0.03$ & $0.531 \pm 0.011$ & $0.57 \pm 0.137$ \\
D & $0.670 \pm 0.174$ & $0.697 \pm 0.04$ & $0.641 \pm 0.2$ & $0.644 \pm 0.155$ \\
H & $1.583 \pm 0.65$ & $1.60 \pm 0.074$ & $1.69 \pm 0.58$ & $1.55 \pm 0.37$ \\
\hline \hline${ }^{\ddagger}$ values of measured parameters are mean \pm SEM & &
\end{tabular}

\section{Trend in assemblages: Hierarchical Cluster Ana- lysis}

Cluster analysis based on bird mean abundance reflects the relationship between the habitat type of studied locations and the bird community assemblage. The resulted cluster separated each unique habitat type inside the lake with the related bird community. The first level separated the lake shores and open water groups from Islet and reed beds habitat groups (Fig. 6). In the second level, every 2 similar groups from the last leveling were further separated.

\section{Bird-indicator species analysis:}

Indicator species analysis has been calculated based on habitat types. The results showed seven bird species with significant indicator values (listed in Table 2). Lake shores, islets and reed beds groups reflected more unique bird species composition. The abundance and occurrence of laughing dove (Streptopelia senegalensis $)(P<0.04)$ was significantly associated with lake shores, which are characterized by domination of human activity and closeness to human settlement. Islet habitats group showed marked number of indicator species, little bittern (Ixobrychus minutus) $(P<0.04)$, pied kingfisher (Ceryle rudis) $(P<0.04)$, Common Kingfisher (Alcedo atthis) $(P<0.02)$, Pied wagtail (Motacilla alba) $(P<0.04)$, Graceful prinia (Prinia gracilis) $(P<0.01)$. Little egret (Egretta garzetta) $(P<0.03)$ favored the reed beds habitat.

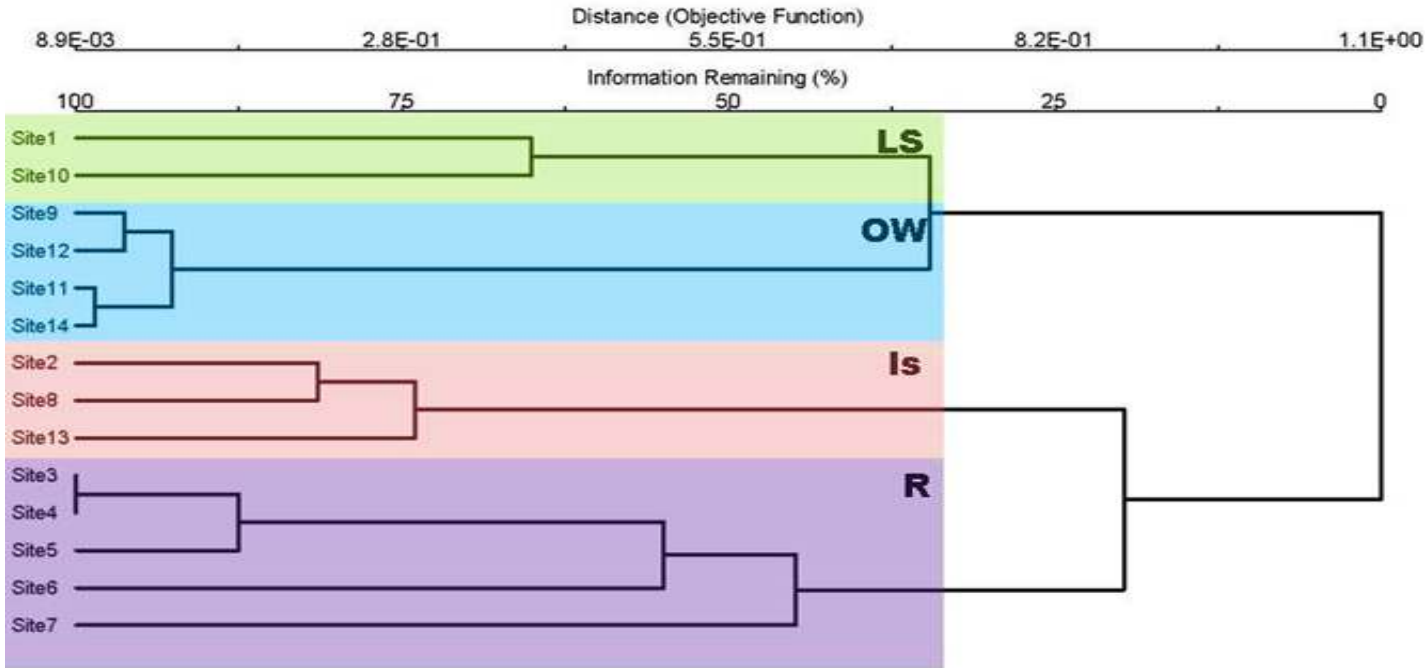

Figure(6): Dendrogram showing the 14 sites interpreted from the Hierarchical Cluster Analysis Classification of the study sites according to their avifauna. Scale represents dissimilarity (1-Sorensen). (LS) Lake shores group, (OW) open water group, (Is) Islet group, (R) reed beds group.

Table (2): Indicators of the grouping produced by CCA of birds recorded from different study sites and their codes.

\begin{tabular}{llll}
\hline \hline Bird species & Group & $\begin{array}{l}\text { Indicator } \\
\text { Value }\end{array}$ & Probability \\
\hline Streptopelia senegalensis & 0 & 74.6 & 0.04 \\
Ixobrychus minutus & 2 & 66.7 & 0.04 \\
Ceryle rudis & 2 & 54.8 & 0.04 \\
Alcedo atthis & 2 & 75.0 & 0.02 \\
Motacilla alba & 2 & 66.7 & 0.04 \\
Prinia gracilis & 2 & 74.3 & 0.01 \\
Egretta garzetta & 3 & 49.0 & 0.03 \\
\hline \hline
\end{tabular}

Different sites has been grouped according to the habitat type (cf. Fig to the following groups: (Lake shores sites (group=0), Lake open-water sites (group=1), Islets sites (group=2), Reed beds sites (group=3).

\section{DISCUSSION}

The importance of this work is that it is the first structured bird survey study focusing on Lake Burullus since the work of Meininger et al. (1986). Data collection and bird surveys are important in evaluating its ecological function. Lake Burullus is unique in its 


\section{Waterbirds biodiversity in Burullus lake Ramsar}

diverse habitats including small islets dominated by dense reed beds scattered in the main water body, which is suitable for sheltering migratory birds and nesting the breeding ones. Habitat heterogeneity inside the lake leads to changes in bird species community composition among different areas.

The present results revealed the importance of the lake as 1) foraging area for all bird species, especially waterbirds consuming fishes, 2) an ideal habitat for reed specialist birds like the migratory Marsh Harrier during all of the winter season, 3) a resting habitat for migratory waterbirds such as herons, waterfowl, gulls and terns, 4) Reed beds provide a good shelter for sleeping birds and a good source for nesting materials of breeding birds, and 5) Open water areas were suitable for large folks of gulls and terns. However, contrary to expectations, there was a marked absence of large breeding colonies at this important Ramsar site. This finding is in agreement with Brandisa et al. (2018), who observed a great decline in colonial breeding birds in different Ramsar sites. Meininger et al. (1986) referred the absence of large colony breeders in the Nile Delta of Egypt (e.g. herons) to the disappearance of isolated, quiet areas and to the enormous degree of disturbance in Nile Delta caused by the presence of a large number of small fishing boats and human settlements. The marked absence of large breeding colonies in the present study can be attributed to many reasons including the great human impact inside the lake and human settlement inside on the lake border. Also, the lake suffered from pollution and uncontrolled and untreated water swage inside it (El-Kafrawy et al., 2015). Such anthropogenic activity was reported to have short and long term impacts on wildlife by inducing changes in behavior, physiology, and reproduction (Burger \& Gochfeld, 1991; Frid \& Dill, 2002).

Species distribution and abundance are affected by the structure of particular habitats and the availability of essential requirements for birds such as diverse food resources, access to dry or mud habitat and nest materials. Lake Burullus is distinguished by variations in soil and water quality which influence each habitat type (El-Kafrawy et al., 2015). There was a clear variation in observed bird population along the different habitat types. The present results showed the diverse habitat of Burullus Lake and how this host wide waterbirds species. Winter season was mainly dominated by migratory waterbirds, while spring season showed absence of migrants and dominance of resident breeder inside the lake. This result is in agreement with that of Ericia et al. (2005) who suggested that differences among bird composition depend on the nature of habitat type, shape and suitability and human land use in the environment.

The results of temporal patterns in relative abundance for the individual species or how these change spatially are of concern for conservation strategies and managements (Harrison et al., 2014). The study showed that the migration reached its peak on February. Abundance of waterbirds, especially cormorants; gulls such as black headed gull, lesser black backed gull, yellow legged gull; ducks such as teal, gargeny, pochard and shoveler, reached the maximum in winter season (Appendix 1). Resident waterbirds, especially whiskered tern, squacco heron, little egret and pied kingfisher showed the highest counts in March with recording of courtship behavior. In May, the breeder birds were the dominant bird in the lake and many birds were collecting nest materials and observed carrying food to return back to feed the juvenile, but no nests were recorded. Temporal change in bird species difference in diversity, community assemblage and richness may be explained by the availability of food and resources. The amount of available resources may be determined by a lot of environmental factors like temperature and precipitation (O'Brien, 1998; Currie, et al, 2004).

In the present study, the species richness variation was studied among different orders of bird species and the results showed that there was a significant difference between different orders of bird species in the number of species and among habitat types group. The highly represented orders were Charadriiformes and Passeriformes. This is because most charadriiformes are water birds, the most abundant group inside the lake. This order was followed by Passeriformes which inhabited mainly the reed beds swamps. Order Cuculiformes was represented only by Senegal coucal inhabiting reed beds swamps and order Falconiformes was represented by the kestrel only.

The results of Hierarchical Cluster Analysis of bird species community separated the bird assemblages according to the different habitat types inside the lake into four distinctive habitats: lake shores, reed beds, open-water areas and islets. The clustering and the indicator species analysis provide the opportunity to identify several species as an indicative of a specific class of sites (Bakker, 2008). Such species, including laughing dove, (Streptopelia senegalensis) was more associated with lake shores near human activity. This is in consistence with Ramesh et al. (2014) who found that laughing dove increased in more urbanized areas in India. Also, the result showed that islet habitats reflect more unique-suitable area to bird community. Five bird species were associated with islet habitat: little bittern, "Ixobrychus minutus", pied kingfisher (Ceryle rudis), Common Kingfisher (Alcedo atthis), Pied wagtail (Motacilla alba), Graceful prinia (Prinia gracilis). Islet habitat offers flat surfaces for birds, which may help in roosting for ground nester and attract carnivore birds for hunting and waders birds who feed on mud surfacees. Masero et al. (2000) recorded high waterbird populations after water dryness or decrease in water depth, which offers more shores, banks, muddy islands and mudflats. Little egret (Egretta garzetta) was associated with reed beds habitat. Reed beds are considered as a refuge habitat due to its ability to colonize many species including birds (Godet et al., 2018). In Japan, Hattori and Mae (2001) found that the high waterbirds diversity is associated with reed beds habitat in lakes, especially in those with people live and work inside.

\section{CONCLUSION}

The present study showed the importance of Lake 
Burllus as a Ramsar and IBA for both the migratory wintering and the breeding waterbirds communities. The habitat variation of Burllus Lake from flat surface provided by the small islets in the water bodies to the open-water, which is dominated in some parts with dense reed beds, makes it unique spot for waterbirds. Monthly bird count is required for better determination of peak activity and land use by bird assemblages. Also, extensive field work, continued bird survey and tracking the environmental change must be done to evaluate the diversity and define the actual need for better conservation action plans.

\section{Acknowledgment}

This work is supported by the "African Bird Club". I am grateful to Dr. Ayman Hyder for his accompany, support during the field work and for the continuous advice during preparing the manuscript and to Mary Megalli for revising and editing the draft.

\section{References}

BAKKER, J. D. 2008. Increasing the utility of Indicator Species Analysis. Journal of Applied Ecology. 45: 1829-1835.

BIRDLIFE INTERNATIONAL. 2018. Important Bird Areas factsheet: Lake Burullus. Downloaded from http://www.birdlife.org on 21/07/2018.

BRANDISA, K.J., G. BINOA, J.A SPENCERB, D. RAMPC, R.T. KINGSFORD, 2018. Decline in colonial waterbird breeding highlights loss of Ramsar wetland function. Biological conservation. 225:22-30

BURGER, J., M. GOCHFELD 1991. Human distance and birds: tolerance and response distances of resident and migrant species in India. Environmental Conservation. 18: 158-165.

CURRIE, D.J., G.G.MITTELBACH, H. V. CORNELL, R. FIELD, J.F. GUEÂGAN, B.A. HAWKINS, D. M. KAUFMAN, J. T. KERR, O. THIERRY, O' BRIEN E, J. R. G. TURNER 2004. Predictions and tests of climate-based hypotheses of broad-scale variation in taxonomic richness. Ecology Letters. 7: 1121-34.

DUFRÊNE, M., P . LEGENDRE, 1997. Species assemblages and indicator species: the need for a flexible asymmetrical approach. Ecological Monographs. 67: 345-366.

EL-BANA, M. I. 2015. Gravel pads of powerline towers as human-made habitats for ruderal vegetation in some Mediterranean wetlands of Egypt: Implications for management. The Egyptian Journal of Aquatic Research. 41: 83-91.

EL-KAFRAWY, S. B., A. KHALAFALLAH, M. OMAR, M. M. H. KHALIL, A. YEHIA, AND M. ALLAM 2015. An integrated field and remote sensing approach for water quality mapping of Lake Burullus, Egypt. International journal of Environmental Science and Engineering. 6: $15-20$

ERICIA, V., B. DEN, Y. TOM AND P. MEIRE 2005. Water bird communities in the Lower Zeeschelde: longterm changes near an expanding harbour. Hydrobiology. 540:237-258.
FARAG, H. AND A. EL-GAMAL 2011. Assessment of the Eutrophic Status of Lake Burullus (Egypt) using Remote Sensing. International journal of Environmental Science and Engineering. 2: 61- 74

FRANCESIAZ, C., E. GUILBAULT, J.D. LEBRETON, J. TROUVILLIEZ, A. BESNARD 2017. Colony persistence in waterbirds is constrained by pond quality and land use. Freshwater Biology. 62 (1): 119-132.

FRID, A., L. DILL 2002. Human-caused disturbance stimuli as a form of predation risk. Conservation Ecology 6: 1-11.

GODET, L., C. HARMANGE, M. MARQUET, E. JOYEUX, J. FOURNIER 2018. Differences in homerange sizes of a bird species in its original, refuge and substitution habitats: challenges to conservation in anthropogenic habitats. Biodiversity and Conservation. 27:719-732.

GREEN, A.J., M. EL HAMZAOUI, M.A. EL AGBANI, J. FRANCHIMONT, 2002. The conservation status of Moroccan wetlands with particular reference to waterbirds and to changes since 1978 . Biological Conservation. 104, 71-82.

HARRISON, S. P., P. J. BARTLEIN, S. BREWER, I. C. PRENTICE, M. BOYD, I. HESSLER, K. HOLMGREN, K. IZUMI, AND K. WILLIS 2014. Climate model benchmarking with glacial and midHolocene climates. Climate Dynamics. 43: 671688.

HATTORI, A. AND S. MAE 2001. Habitat use and diversity of waterbirds in a coastal lagoon around Lake Biwa, Japan. Ecological Research 16: 543553.

MA, Z., Y. CAI, B. LI, J. CHEN 2010. Managing Wetland Habitats for Waterbirds: An International Perspective. Wetlands. 30: 15-27.

MASERO, J. A., A. PEREZ-HURTADO, M. CASTRO AND G. M. ARROYO 2000. Complementary use of intertidal mudflats and adjacent Salinas by foraging waders. Ardea. 88:177-191.

MASOUD, M. S., M. A. FAHMY, A. E. ALI AND E. A. MOHAMED 2011. Heavy metal speciation and their accumulation in sediments of Lake Burullus, Egypt. African Journal of Environmental Science and Technology. 5(4): 280-298.

MCCUNE, B., M.J. MEFFORD 2011. PCORD. Multivariate analysis of ecological data. Version 6.0. Gleneden Beach: MjM Software Design.

MEININGER, P.L. AND G.A.M., ATTA 1994. Ornithological studies in Egyptian wetlands 1989/ 1990. FORE Report 94-01/WIWO Report 40 (Vlissingen/Zeist, the Netherlands).

MEININGER, P.L., U.G. SORENSON AND G.A.M. ATTA 1986. Breeding birds of the lakes in the Nile Delta, Egypt. Sandgrouse, 7: 1-20.

O'BRIEN, E.M. 1998. Water-energy dynamics, climate, and prediction of woody plant species richness: an interim general model. Journal of Biogeography.25: 379-398.

RAJPAR, M.N. AND M. ZAKARIA 2013. Assessing an artificial wetland in Putrajaya, Malaysia, as an alternate Habitat for waterbirds. Waterbirds. 36: 482-493. 


\section{Waterbirds biodiversity in Burullus lake Ramsar}

RAMESH, M., R. NIJAGUNAPPA, K. MANJUNATH 2014. Urbanization impact on avifauna population and its status in Gulbarga city, Karnataka, India. International Letters of Natural Sciences. 26: 36-46.

RAMSAR CONVENTION SECRETARIAT, 2016. An Introduction to the Convention on Wetlands. Ramsar Convention Secretariat, Gland, Switzerland.

ROBLEDANO, F., M. A. ESTEVE, P. FARINÓS, M. F. CARREÑO AND J. MARTÍNEZ-FERNÁNDEZ 2010. Terrestrial birds as indicators of agriculturalinduced changes and associated loss in conservation value of Mediterranean wetlands. Ecological Indicators. 10: 274-286.

SAYOUD, M.S., H. SALHI, , B. CHALABI, A. ALLALI , M. DAKKI , A. QNINBA, M.A. EL AGBANI, H. AZAFZAF, C. FELTRUPAZAFZAF, H. DLENSI, N. HAMOUDA, W. ABDEL LATIF IBRAHIM, H. ASRAN, A. ABU ELNOOR, H. IBRAHIM, K. ETAYEB, E. BOURAS, W. BASHAIMAM, P. DEFOS DU RAU 2017. The first coordinated trans North African mid-winter waterbird census: The contribution of the International Waterbird Census to the conservation of waterbirds and wetlands at a biogeographical level. Biological Conservation. 206: $11-20$

SHALTOUT, K. H. AND M. T. KHALIL 2005. Lake Burullus (Burullus Protected Area). Publication of National Biodiversity Unit, No. 13, Egyptian Environmental Affairs Agency, Egypt, p. 578.

SHREADAH, M. A., S. A. ABDEL GHANI, H. B. I. HAWASH, ABD A. EL SAMIE, A-.E-M. M. AHMED 2014. Organotin Compounds in Sediments of Northern Lakes, Egypt. Journal of Environmental Protection. 5: 1654-1666.

TIEGA, A. 2011. Ramsar Convention on Wetlands: 40 Years of Biodiversity Conservation and Wise Use. Journal of International Wildlife Law \& Policy 14: $173-175$.

XIA, S., X. YU, S. MILLINGTON, Y. LIU, Y. JIA, L. WANG, X. HOU, L. JIANG 2017. Identifying priority sites and gaps for the conservation of migratory waterbirds in China's coastal wetlands. Biological Conservation, 210: 72-82.

\section{التنوع البيولوجي واستخدام الموائل للطيور المائية الثتوية و المتزاوجة في بحيرة البرلس (موقع رامسار) ،}

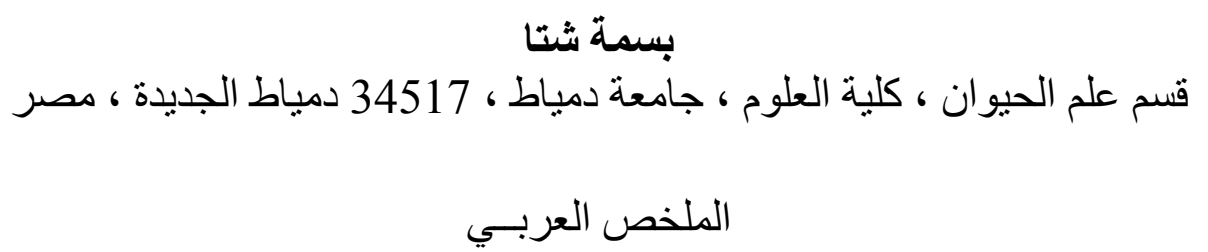

تسعى هذه الدراسة إلى تقييم ودر اسة التنوع البيولوجي للطيور في واحد من احدي المو اقع الهامة للطيور وموقع رامسار ، بحيرة البرلس، شمال مصر. تم تقييم التنوع البيولوجي للطيور المائية في 14 موقعًا محددًا حول البحيرة خلال فصلي الثتاء و الربيع. شمل تقييم التنوع البيولوجي قياس التنوع في عدد الانو اع و عدد الأفر اد والتركيب المجتمي للطيور ومقاييس قياس التنوع سبمسون وشانون خلال فترة الدراسة.وتباين التنوع البيولوجي بين أنواع الطيور من حيث المكان و الزمان بين المواقع المختلفة. واوضحت النتائج ان عدد الأنواع المتو اجده يقدر ب 49 نوعًا. كانت الطيور الثنتوية بشكل أساسي منمثله في الطيور المائية المهاجرة مثل

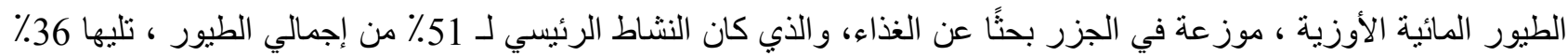
من الطيور المقيمة و 13٪ هي نسبة الطيور المنزاوجه في البحيرة. تم تسجيل أدله على عملية التزاوج ، مثل جمع المواد اللازمة لبناء العش ، وسلوك الغزل وجمع المو اد الغذائية للصغار. أوضحت نتائج التحليل التسلسلي الهرمي العنقودي، Hierarchical Cluster Analysis تجمعات نبات الغاب. كما أوضح تحليل الدليل أو المؤشر لأنواع الطيور وجود سبعة أنوان أنواع من أنواع الطيور لهم دلالة معنوية بمواقع الدراسة. اليمام البلدي وكان مرتبط بشواطيء البحيرة. بينما طيور الواق الصغير و صياد السمك الأبقع وصياد السمك

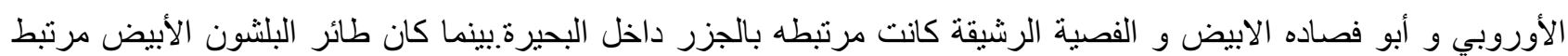
بمجتمعات الغاب داخل البحيرة.تعكس النتائج أهية بحيرة البرلس كمشتي للطيور المهاجرة الثنتية في فصل الثتاء للطيور

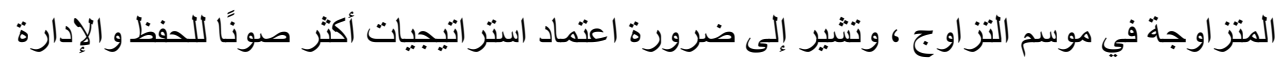




\section{Sheta, B.M.}

Appendix 1. List of the birds has been recorded a long the study, and species distribution in the lake habitats. (0) indicates absence and (1) indicates presence. Lake Shores (LS), Open Water (OW), (Is) Islets, (R) Reed beds. (x) Presence in season.

\begin{tabular}{|c|c|c|c|c|c|c|c|}
\hline \multirow{2}{*}{ Scientific Name } & \multirow{2}{*}{ Common Name } & \multirow{2}{*}{ Winter } & \multirow{2}{*}{ Spring } & \multicolumn{4}{|c|}{ Habitat } \\
\hline & & & & $\mathbf{L S}$ & OW & Is & $\mathbf{R}$ \\
\hline Little Grebe & Tachybaptus ruficollis & $\mathrm{x}$ & & 0 & 0 & 1 & 1 \\
\hline Cormorant & Phalacrocorax carbo & $\mathrm{x}$ & & 0 & 1 & 1 & 1 \\
\hline Little bittern & Ixobrychus minutus & & $\mathrm{x}$ & 0 & 0 & 1 & 1 \\
\hline Little egret & Egretta garzetta & $\mathrm{x}$ & $\mathrm{x}$ & 1 & 1 & 1 & 1 \\
\hline Squacco heron & Ardeola ralloides & $\mathrm{x}$ & $\mathrm{x}$ & 1 & 1 & 1 & 1 \\
\hline Cattle egret & Bubulucus ibis & $\mathrm{x}$ & $\mathrm{x}$ & 1 & 1 & 0 & 0 \\
\hline Grey heron & Ardea cinerea & & $\mathrm{x}$ & 0 & 0 & 0 & 1 \\
\hline Night heron & Nicticorax nicticorax & $\mathrm{x}$ & $\mathrm{x}$ & 1 & 0 & 1 & 0 \\
\hline Garganey & Anas querquedula & $\mathrm{x}$ & & 0 & 0 & 1 & 0 \\
\hline Shoveler & Anas clypeata & $\mathrm{x}$ & & 0 & 0 & 1 & 1 \\
\hline Pochard & Aythya ferina & $\mathrm{x}$ & & 0 & 0 & 1 & 0 \\
\hline Marsh harrier & Circus aeruginosus & $\mathrm{x}$ & & 1 & 1 & 1 & 1 \\
\hline Kestrel & Falco tinnunculus & & $\mathrm{x}$ & 0 & 0 & 0 & 1 \\
\hline Eurasian coot & Fulica atra & & $\mathrm{x}$ & 0 & 0 & 1 & 0 \\
\hline Purple swamphen & Porphyrio porphyria & & $\mathrm{x}$ & 0 & 1 & 0 & 1 \\
\hline Common moorhen & Gallinula chloropus & $\mathrm{x}$ & $\mathrm{x}$ & 0 & 1 & 1 & 1 \\
\hline Spur-winged lapwing & Hoplopterus spinosus & $\mathrm{x}$ & $\mathrm{x}$ & 1 & 0 & 1 & 1 \\
\hline Marsh sandpiper & Tringa stagnatilis & $\mathrm{x}$ & $\mathrm{x}$ & 0 & 1 & 0 & 0 \\
\hline Redshank & Tringa tetanus & $\mathrm{x}$ & $\mathrm{x}$ & 0 & 1 & 0 & 0 \\
\hline Armenian gull & Larus armenicus & & $\mathrm{x}$ & 0 & 1 & 1 & 1 \\
\hline Black headed gull & Larus ridibundus & $\mathrm{x}$ & $\mathrm{x}$ & 1 & 1 & 1 & 1 \\
\hline Slender billed gull & Larus genei & $\mathrm{x}$ & $\mathrm{x}$ & 1 & 1 & 1 & 1 \\
\hline Yellow legged gull & Larus cachinnans & & $\mathrm{x}$ & 1 & 0 & 0 & 0 \\
\hline Lesser black backed gull & Larus fuscus & $\mathrm{x}$ & $\mathrm{x}$ & 1 & 1 & 1 & 1 \\
\hline Different immature gull & Larus spp. & $\mathrm{x}$ & $\mathrm{x}$ & 1 & 1 & 1 & 1 \\
\hline Little tern & Sterna albifrons & $\mathrm{x}$ & $\mathrm{x}$ & 0 & 1 & 1 & 1 \\
\hline White wingedblack tern & Chlidonias leucopterus & & $\mathrm{x}$ & 1 & 0 & 0 & 0 \\
\hline Whiskered tern & Chlidonias hybridus & $\mathrm{x}$ & $\mathrm{x}$ & 1 & 1 & 1 & 1 \\
\hline Gull billed tern & Gelochelidon nilotica & $\mathrm{x}$ & $\mathrm{x}$ & 1 & 1 & 0 & 0 \\
\hline
\end{tabular}


Waterbirds biodiversity in Burullus lake Ramsar

\begin{tabular}{|c|c|c|c|c|c|c|c|}
\hline \multicolumn{8}{|c|}{ Appendix (1): Continue } \\
\hline \multirow{2}{*}{ Scientific Name } & \multirow{2}{*}{ Common Name } & \multirow{2}{*}{ Winter } & \multirow{2}{*}{ Spring } & \multicolumn{4}{|c|}{ Habitat } \\
\hline & & & & $\mathbf{L S}$ & OW & Is & $\mathbf{R}$ \\
\hline Laughing dove & Streptopelia senegalensis & & $\mathrm{x}$ & 1 & 0 & 1 & 1 \\
\hline Turtle dove & Streptopelia turtur & & $\mathrm{x}$ & 0 & 0 & 1 & 1 \\
\hline Senegal coucal & Centropus senegalensis & & $\mathrm{x}$ & 0 & 0 & 0 & 1 \\
\hline Blue checked bee eater & Meropus superciliosus & & $\mathrm{x}$ & 0 & 0 & 1 & 0 \\
\hline Hoopoe & Upupa epops & & $\mathrm{x}$ & 1 & 0 & 0 & 0 \\
\hline Pied kingfisher & Ceryle rudis & $\mathrm{x}$ & $\mathrm{x}$ & 1 & 1 & 1 & 1 \\
\hline White throated kingfish. & Halcyon smyrnensis & $\mathrm{x}$ & & 0 & 1 & 1 & 1 \\
\hline Common kingfisher & Alcedo atthis & $\mathrm{x}$ & & 0 & 0 & 1 & 1 \\
\hline Sand martin & Riparia riparia & & $\mathrm{x}$ & 1 & 1 & 1 & 1 \\
\hline Barn swallow & Hirundo rustica transitiva & & $\mathrm{x}$ & 1 & 1 & 1 & 0 \\
\hline Barn swallow & Hirundo rustica savigmii & & $\mathrm{x}$ & 1 & 1 & 1 & 0 \\
\hline Pied wagtail & Motacilla alba & $\mathrm{x}$ & & 0 & 0 & 1 & 0 \\
\hline Yellow wagtail & Motacilla flava & & $\mathrm{x}$ & 0 & 0 & 1 & 1 \\
\hline Hooded crow & Corvus corone cornix & $\mathrm{x}$ & $\mathrm{x}$ & 1 & 1 & 1 & 1 \\
\hline Graceful prinia & Prinia gracilis & $\mathrm{x}$ & $\mathrm{x}$ & 0 & 1 & 1 & 1 \\
\hline Clamorous reed warbler & Acrocephalus stentoreus & & $\mathrm{x}$ & 0 & 0 & 1 & 1 \\
\hline Great reed warbler & Acrocephalus arundinaceus & $\mathrm{x}$ & $\mathrm{x}$ & 0 & 1 & 1 & 1 \\
\hline Blackbird & Turdus merula & $\mathrm{x}$ & & 0 & 1 & 0 & 0 \\
\hline Redstart & Phoenicurus phoenicurus & $\mathrm{x}$ & & 0 & 0 & 1 & 0 \\
\hline Common bulbul & Pycnonotus barbatus & & $\mathrm{x}$ & 0 & 0 & 1 & 0 \\
\hline House sparrow & Passer domesticus niloticus & & $\mathrm{x}$ & 1 & 0 & 0 & 0 \\
\hline
\end{tabular}

